\title{
Neurosecretory Phenomena of the Ganglion Cells in the Adrenal Medulla of the Golden Hamster
}

\author{
By \\ Takashi Ito \\ Department of Anatomy, Nagoya University School of Medicine, Nagoya \\ (Director: Prof. Ch. Togari)
}

It is now well known that the hypothalamic neurones in the supraoptic and paraventricular nuclei have secretory activity. Concerning this problem a detailed information has been presented by many investigators, especially Scharrer and his co-workers, and Bargmann and his associates (For extensive references and reviews see: Bargmann, 1953; Scharrer, 1954).

On the other hand, considerable interest has lately centred around the neurosecretion in peripheral neurones. Gaupp $(1938,1939)$ was the first to give a special attention to such phenomena in the sympathetic ganglion in man, although his opinion was opposed by Herzog (1938), Stöhr (1939), and Meyer (1950). Meanwhile, in recent years, evidence in support of the view of Gaupp has been presented by several authors. For instance, the neurosecretory phenomena of the peripheral ganglion cells were reported at the myenteric plexus of the rat (Ito and Nagahiro, 1937), the periadrenal ganglion of the monkey (Lennette and Scharrer, 1946), the adrenal medulla of the golden hamster (Eichner, 1951) and of man and the horse (Picard and Chambost, 1953), the sympathetic trunk, particularly stellate ganglion of several mammalian species (Eichner, 1952), and the ganglion cervicale uteri of the rat (Lehmann and Stange, 1953).

In the course of a study of the histogenesis of the adrenal gland in the golden hamster, I also observed very peculiar features, interpreted by Eichner (1951) as neurosecretory phenomena, in the ganglion cells in the medulla. It is hoped that the present observations, though essentially in agreement with those of Eichner, may contribute some further information on this subject. 


\section{Material and Methods}

The material used in this investigation consisted of part of that to be employed in a study of the histogenesis of the adrenal gland of the golden hamster. Eighty-one hamsters of both sexes, from birth to 200 days were studied. The adrenal glands were fixed in Bouin's and Zenker's fluids. After embedding in paraffin, serial sections $5 \mu$ thick were cut and stained mostly with hematoxylin and eosin and partly with iron hematoxylin.

\section{Observations}

Differentiation of the ganglion cells

At birth, the medullary tissue is irregularly intermingled with the cortical one. It contains a few groups of sympathetic formative cells, that is, sympathogonia, which are the undifferentiated forms of both the chromaffine cells and the ganglion cells (fig. 1). The features of the sympathogonia are quite similar to those of the sympathogonia in the guinea pig (Ito, 1953). They are closely packed, and are very small cells with little cytoplasm and relatively darkly-staining nuclei. The nuclei contain several, very prominent round nucleoli or chromatin clumps which are characteristic of the nuclei of these cells. At one day of age, some of the sympathogonia begin to differentiate in the ganglion cell direction, and become transformed to sympathoblasts. The sympathoblasts are increased in volume of both cytoplasm and nucleus, when compared with the sympathogonia. They are arranged in small groups like a syneytium without any distinct cell outline. At 3 days, the medullary tissue becomes aggregated toward the center of the gland. The sympathoblasts arranged in small masses are generally found near or close to the cortico-medullary boundary. In the age of 4 to 9 days, as the maturation proceeds, they acquire more and more cytoplasm which stains with basic dyes, and their nuclei become gradually enlarged and vesicular with a few nucleoli. Then, on the 10th day these cells have the characteristic appearance of the fully developed ganglion cell (fig. 2). The cell body constitutes an abundant mass of cytoplasm which generally contains considerable amount of Nissl substance around the periphery. The nuclei, located centrally or somewhat eccentrically, are large, round and very pale with usually one prominent nucleolus. The ganglion cells generally occur in groups of varying size but sometimes singly. In many cases, they lie in the periphery of the medulla. 


\section{Characteristic features of the ganglion cells}

As just mentioned, the ganglion cells undergo rapid maturation during 10 days after birth. Thereafter, the greater majority of them show distinctive intracellular inclusions which give these cells a very characteristic appearance (figs. 3, 4).

With the usual fixatives and stains, the inclusions occur, for the most part, as vacuoles of large size. Most frequently a single vacuole is seen in a cell, but sometimes two or more may occur. The contents of the vacuoles are dissolved, or they appear as a finely granular, eosinophilic substance containing a few smaller, colorless vacuoles. Inclusions of large size occupy the major part of the cell body, so that the nucleus and cytoplasm are displaced toward the periphery of the cell. This gives such cell a signetring-like appearance. The very large vacuoles measuring over $50 \mu$ in their diameter appear as a large, round or oval space enclosed by a capsule. Yet, when traced through serial sections, such a space is found containing the nucleus and cytoplasm within itself. Further, the ganglion cells occasionally show a small clear area, faintly stained with eosin, in their cytoplasm. In some cases, such an area is found transformed into a small vacuole. Certain cells, though rarely, contain a homogeneous, eosinophilic mass which is usually known as colloid.

The nuclei of the inclusion-bearing ganglion cells exhibit little changes in appearance as compared with those of the cells containing no inclusions. In some cases the nucleoli are more or less increased in number as stated by Eichner (1951), but this is not always the case. At any rate, whether the ganglion cells contain inclusions or not, their nuclei at least do not show any of the signs associated with cellular activity. In no case, the nuclei show any degenerative changes.

The inclusions become evident, for the first time, as small colorless vacuoles at 10 days of age (fig. 2). Then, the formation of vacuolation proceeds rapidly, and at 12 days the ganglion cells contain striking vacuoles, showing a characteristic signetring-like appearance (fig. 3). From this time onwards, the intracellular inclusions are common among the ganglion cells, and their occurrence appears to be independent of sex.

\section{Discussion}

Of particular interest is the occurrence of the intracellular inclusions in the ganglion cells in the adrenal medulla of the golden 
hamster. It is questionable, however, whether these features may be regarded as cytological aspects associated with secretory activity.

In many animals, it has been established that the hypothalamic neurones contain Gomori-positive granules in their cytoplasm, and further, that these granules are the characteristic manifestation of neurosecretion. In the hypothalamic neurosecretion, the secretory materials are known to appear generally in the form of such granules instead of vacuoles. The vacuoles, if any, are reported to be of rare occurrence (Palay, 1953).

Unlike the hypothalamic neurosecretion, the neurosecretion in the peripheral neurones is, in many cases, reported to be manifested by the cytoplasmic inclusions just as is seen in the ganglion cells in the medulla of this animal (Eichner, 1951; Picard and Chambost, 1953; Eichner, 1952; Lehmann and Stange, 1953). However, such inclusions, particularly vacuoles, are regarded by some authors as postmortem artificial products (Herzog, 1938; Stöhr, 1939; Meyer, 1950), or as degenerative changes, particularly aged ones (Unger, 1951 ; Ehlers, 1951). Against such objections, the school of Bargman n maintain that the vacuolated ganglion cells are not degenerative in character, because their nuclei show no degenerative changes.

The present observations also support the view that the inclusions in question, particularly vacuoles, are due to cellular functional activity and not to degenerative process. In no case I have seen figures that would indicate cellular degeneration. In addition to vacuoles of varying size, the ganglion cells here sometimes contain the inclusions such as are seen in the glandular cells of the endocrine organs. Therefore, the occurrence of these inclusions may be regarded as indicating the secretory activity of the cells. Further, simultaneously with the differentiation, that is, at 10 days of age, the ganglion cells begin to show inclusions, which later are almost of constant occurrence at nearly all the greater ages so far examined. From these findings, it may be said that the neurosecretory activity here becomes evident early in life and persists probably throughout life.

\section{Summary}

During the first 10 days of life, the ganglion cells in the adrenal medulla of the golden hamster differentiate from the sympathogonia after passing through the stage of sympathoblasts. Thereafter the ganglion cells show varying inclusions in the cytoplasm, which give a 
characteristic feature to these cells. These inclusions are regarded as the manifestation of the neurosecretory activity of the cells. Such activity becomes evident simultaneously with the maturation of the ganglion cells, and persists probably throughout life.

I wish to express my sincere appreciation to Professor $\mathrm{Ch}$. Togari for his encouragement and criticisms during the course of this work.

\section{Literature Cited}

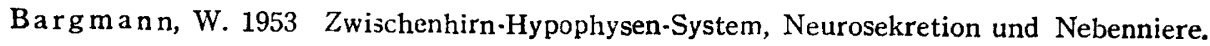
Geburtshilfe u. Frauenheilkunde, 13. Jahrg., S. 193-212.

Ehlers, P. 1951 Anat. Anz., Bd. 98, S. 24 (Quoted by Eichner, 1952).

Eichner, D. 1951 Zur Frage der Neurosekretion der Ganglienzellen des Nebennieren. markes. Z. Zellforsch., Bd. 36, S. 293-297.

1952 Zur Frage der Neurosekretion in den Ganglienzellen des Grenzstranges. Z. Zellforsch., Bd. 37, S. 274-280.

Herzog, E. 1938 Zur Frage des Pigmentes und einer möglichen Neurosekretion in den sympathischen Ganglien. Beitr. path. Anat, Bd. 101, S. 390-409.

Ito, Takashi 1953 Observations on the development and structure of the adrenal medulla in the guinea pig. Folia anat. jap., vol. 25, pp. 37-49.

Ito, Toshio, und K. Nagahiro 1937 Zytologische Untersuchungen über die intramuralen Ganglienzellen des Verdauungstraktes. Über die Ganglienzellen der Darmwand der Ratte, mit besonderer Berücksichtigung auf die Sekretkörnchen ähnlichen Granula in den intramuralen Ganglienzellen. Folia anat. jap., Bd. 15, S. 609-634.

Gaupp, R. 1938 Die Neurosekretion des Sympathicus. Z. Neur., Bd. 160, S. 357-360 (Quoted by Scharrer, 1954).

1939 Die morphologischen Grundlagen zur Theorie einer Neurosekretion des vegetativen Systems. Z. Neur., Bd. 165, S. 273-278 (Quoted by Scharrer, 1954).

Lehmann, H.J., und H.H. Stange 1953 Über das Vorkommen vakuolenhaltiger Ganglienzellen im Gangion cervicale uteri trächtiger und nichtträchtiger Ratten. Z. Zellforsch., Bd. 38, S. 230-236.

Lennette, E.H., and E. Scharrer 1946 Neurosecretion. IX. Cytoplasmic inclusions in peripheral autonomic ganglion cells of the monkey. Anat. Rec., vol. 94, pp. 85-92 (Quoted by Scharrer, 1954).

Meyer, E. R. 1950 Zur Frage der Neurosekretion sympathischer Ganglien nach Untersuchungen des Ganglion stellatum bei Tier und Mensch. Beitr. path. Anat., Bd. 111, S. 373-380 (Quoted by Scharrer, 1954).

Palay, S.L. 1953 Neurosecretory phenomena in the hypothalamo-hypophysial system of man and monkey. Am. J. Anat., vol. 93, pp. 107-127.

Picard, D., et Mme Chambost 1953 La neuro-sécrétion dans les amas gangionnaires sympathiques intra surrénaux. C. r. Ass. Anat., Réunion 39, pp. 167-173.

Scharrer, E., und B. Scharrer 1954 Neurosekretion. In Handbuch der mikroskopisch. en Anatomie des Meschen (W. Möllendorff und W. Bargmann) VI/5, Springer, Berlin $\cdot$ Göttingen $\cdot$ Heidelberg.

Stöhr, jr. P. 1939 Über „Nebenzellen “ und deren Innervation in Ganglien des vegeta- 
tiven Nervensystems, zugleich ein Beitrag zur Synapsenfrage. Z. Zellforsch., Bd. 29, S. 569-612.

Unger, K. 1951 Anat. Anz., Bd. 98, S. 13 (Quoted by Eichner, 1952).

\section{Explanation of Figures}

All the figures are photographs of specimens fixed in Zenker-formol-acetic and stained with hematoxylin and eosin.

1. A male at birth. Group of sympathogonia in the medullary tissue. $\times 800$

2. A male at 10 days of age. Differentiated ganglion cells. Two of them show vacuoles in the cytoplasm. $\times 800$

3. A male at 12 days of age. Ganglion cells containing large vacuoles. $\times 800$

4. A female at 35 days of age. Ganglion cells possessing very characteristic intracellular inclusions of large size. $\times 800$ 

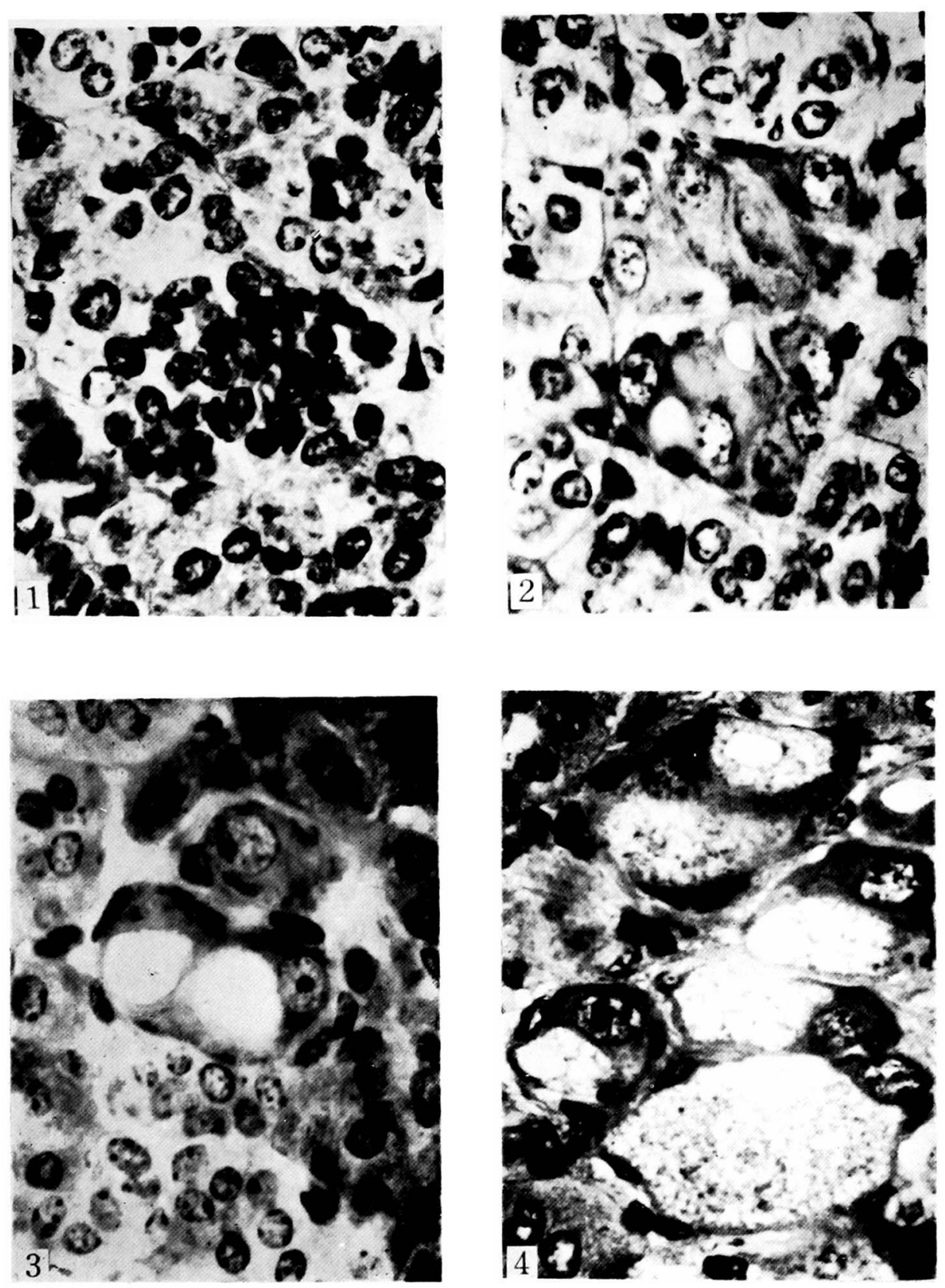

T. Ito 